\title{
Knowledge, attitude and practice of contraception among nursing and para-medical staff in a tertiary care hospital of Mathura, Uttar Pradesh, India
}

\author{
Parul Garg* \\ Department of Obstetrics and Gynecology, K. D. Medical College, Hospital and Research Center, Mathura, Uttar \\ Pradesh, India
}

Received: 18 April 2020

Accepted: 27 April 2020

\author{
*Correspondence: \\ Dr. Parul Garg, \\ E-mail: parulgarg.dr79@gmail.com
}

Copyright: ( ) the author(s), publisher and licensee Medip Academy. This is an open-access article distributed under the terms of the Creative Commons Attribution Non-Commercial License, which permits unrestricted non-commercial use, distribution, and reproduction in any medium, provided the original work is properly cited.

\begin{abstract}
Background: The objective of this study was to study the knowledge, attitude and practice of contraception among nursing and para-medical staff in a tertiary care hospital and also to identify factors that are associated with non-usage of contraception.

Methods: The study was conducted on 100 nursing and paramedical staff working at K. D. Medical College and associated hospital at Mathura from November 2019 to January 2020. After obtaining consent, randomly selected married nursing and paramedical staff were given a pre-designed, structured questionnaire on socio-demographic variables, knowledge, attitude and practice towards contraception.

Results: In the present study, out of 100 participants, 89 had awareness of contraception. Majority of them knew about condoms, followed by Copper-T/multiload and OCPs. The knowledge about contraception was mainly obtained through social media and health professionals.

Conclusions: Health care providers should be equipped with recent information on all the available family planning methods through intensive in-service trainings, seminars/conferences, etc. This will get them informed and all misconceptions will be erased and in turn each health care provider will be able to make informed choice from the various options of family planning methods and practice the best suitable method.
\end{abstract}

Keywords: Attitude, Knowledge, Nursing, Para-medical staff, Practice

\section{INTRODUCTION}

Contraception is one of the proximate determinants of fertility and the most important predictor of fertility transition. Family planning refers to a conscious effort by a couple to limit or space the number of children they have through the use of contraceptive methods. ${ }^{1}$ Family planning deals with reproductive health of the mother, having adequate birth spacing, avoiding undesired pregnancies and abortions, preventing sexually transmitted diseases, and improving the quality of life of mother, fetus, and family as a whole. A woman can get pregnant if one of man's sperm reaches her egg (ovum).
Contraception tries to stop this either by stopping egg production or by keeping the egg and the sperm apart or by stopping the implantation of the fertilized egg into the uterus. Contraception in the simplest terms is the prevention of pregnancy and contraceptive methods, by definition, are the preventive methods to help women avoid unwanted pregnancies. ${ }^{2}$

India is the second most populated country in the world. Uncontrolled population growth is recognized as the single most important impediment to national development. Despite the fact that India was the first country in the world to implement a national population 
control programme in 1952, the country is still struggling to contain the baby boom. ${ }^{3}$ A lot of efforts and resources have gone into the National family welfare programme but the returns are not commensurate with the inputs. The programme has targeted eligible couples in its efforts to control the population.

Each year approximately 210 million women become pregnant worldwide and 80 million pregnancies are unplanned. About 46 million (22\%) end in induced abortion and 68,000 women die because of unsafe abortion. ${ }^{4}$ In India, complications of unsafe abortion account for an estimated $9 \%$ of all maternal deaths. ${ }^{5}$ Use of contraceptives can prevent at least $25 \%$ of all maternal deaths by preventing unintended pregnancies and unsafe abortions and also protect against sexually transmitted infections, such as human immunodeficiency virus (HIV), chlamydia, syphilis, etc. ${ }^{6}$ A lack of knowledge of contraceptive methods, source of supply, cost, or poor accessibility are the barriers that exist in developing countries. ${ }^{7}$

Health care professionals including doctors, nursing staff, paramedical staff and other hospital staff members represent an important bridge between the general population to impact knowledge of contraception and other family planning methods. Nursing personnel act as both health educators and service providers. Their understanding about contraception can grossly influence the contraceptive practices of the community. However it has been seen that mere knowledge of contraception among health care professional is not the only important factor but their own attitude and practices of contraception play an important role in imparting and advising methods to the general population which is often seen lacking which could be the contributing factor towards malpractice of contraception in society. Therefore, this study was aimed to assess the knowledge, attitude and practice of contraception among nursing and paramedical staff.

\section{METHODS}

This was a cross-sectional study conducted by the department of obstetrics and gynecology at K. D. Medical College and Associated Hospital, Mathura from $1^{\text {st }}$ November 2019 to $31^{\text {st }}$ January 2020. The study was conducted on 100 nursing and paramedical staff working in the hospital to assess their knowledge, attitude and practice of contraception.

\section{Inclusion criteria}

- Married (both males and females) nursing and paramedical staff.

\section{Exclusion criteria}

- Married nursing and paramedical staff who refused to take part in the study.
- Unmarried nursing and paramedical staff.

After obtaining the ethical committee approval, randomly selected married male and female nursing and paramedical staff who gave consent were included to participate in the study. A written pre-designed, structured questionnaire was given to the participants which included questions on socio-demographic details like age, sex religion, area of residence, type of family, duration of marriage, parity and history of abortions whether spontaneous or induced.

The participants were also asked all types of questions which could help us to assess their knowledge, attitude and practice regarding contraception. The questionnaire enquired about source of knowledge regarding contraception, whether they obtained from social media, health workers, relatives and friends, course education etc.

The questionnaire also enquired the reason of not using contraception among non-users of contraception like fear of side-effects, want for male child, inconvenient or expensive to use, apprehension regarding future fertility, religious belief, partner objection etc. Confidentiality of information provided was assured and maintained.

\section{Statistical analysis}

The responses were entered in Excel spreadsheet and later analysed using SPSS software version 25.

\section{RESULTS}

The socio-demographic characteristics of study participants in respect to age was maximum (64\%) in age group between 20-29 years. Sex distribution was $38 \%$ for males and $62 \%$ for females. Among the participants, $47 \%$ had parity equal to or greater than 3 (Table 1).

Regarding knowledge on different contraceptive methods, out of 100 participants, 89 had awareness of contraception. Majority of them knew about condoms, followed by Copper-T/multiload and OCPs. The participants who had knowledge about contraceptive methods, they mainly obtained it from social media and health professionals. Majority (84\%) agreed on avoidance of unwanted pregnancy as benefit of contraception (Table 2).

Out of 100 nursing and para-medical staff regarding practice of contraception, twenty-three participants were not using any of the method. Condoms (20\%) were mostly used followed by OCPs (Table 3 ).

The attitude of twenty-three non-users of contraception was obtained. Majority found inconvenient to use contraception while many found contraceptives expensive to use and associated with side effects (Table 4). 
Table 1: Socio-demographic characteristics of participants $(n=100)$.

\begin{tabular}{|c|c|c|c|}
\hline Characteristics & Category & Number & Percentage \\
\hline \multirow{3}{*}{ Age in years } & $20-29$ & 64 & $64.0 \%$ \\
\hline & $30-39$ & 27 & $27.0 \%$ \\
\hline & $\geq 40$ & 9 & $9.0 \%$ \\
\hline \multirow{2}{*}{ Sex } & Male & 38 & $38.0 \%$ \\
\hline & Female & 62 & $62.0 \%$ \\
\hline \multirow{3}{*}{ Religion } & Hindu & 69 & $69.0 \%$ \\
\hline & Muslim & 11 & $11.0 \%$ \\
\hline & Others & 20 & $20.0 \%$ \\
\hline \multirow[t]{2}{*}{ Residential area } & Rural & 54 & $54.0 \%$ \\
\hline & Urban & 46 & $46.0 \%$ \\
\hline \multirow{2}{*}{ Type of family } & Nuclear & 57 & $57.0 \%$ \\
\hline & Joint & 43 & $43.0 \%$ \\
\hline \multirow{2}{*}{ Income of the family/month } & $<15000$ & 73 & $73.0 \%$ \\
\hline & $\geq 15000$ & 27 & $27.0 \%$ \\
\hline \multirow{2}{*}{ Duration of marriage in years } & $<5$ years & 43 & $43.0 \%$ \\
\hline & $\geq 5$ years & 57 & $57.0 \%$ \\
\hline \multirow{3}{*}{ Parity } & Nulliparous & 21 & $21.0 \%$ \\
\hline & $<3$ & 32 & $32.0 \%$ \\
\hline & $\geq 3$ & 47 & $47.0 \%$ \\
\hline \multirow{2}{*}{ History of abortion } & Yes & 74 & $74.0 \%$ \\
\hline & No & 26 & $26.0 \%$ \\
\hline \multicolumn{2}{|l|}{ No. of spontaneous abortions } & 38 & $51.4 \%$ \\
\hline \multicolumn{2}{|l|}{ No. of Induced abortions } & 36 & $48.6 \%$ \\
\hline
\end{tabular}

Table 2: Knowledge about contraception among participants $(n=100)$.

\begin{tabular}{|c|c|c|c|}
\hline \multicolumn{2}{|l|}{ Knowledge variables } & Number & Percentage \\
\hline \multirow{2}{*}{ Awareness of contraception } & Yes & 89 & $89.0 \%$ \\
\hline & No & 11 & $11.0 \%$ \\
\hline \multirow{8}{*}{$\begin{array}{l}\text { Contraceptive methods known* } \\
(\mathrm{n}=89)\end{array}$} & Condoms & 89 & $100.0 \%$ \\
\hline & Oral contraceptive pills & 68 & $76.4 \%$ \\
\hline & Injection depo-provera & 32 & $35.9 \%$ \\
\hline & Copper-T/multiload & 79 & $88.7 \%$ \\
\hline & Norplant & 14 & $15.7 \%$ \\
\hline & Emergency contraception & 73 & $82.0 \%$ \\
\hline & Female sterilization & 81 & $91.0 \%$ \\
\hline & Male sterilization & 28 & $31.4 \%$ \\
\hline \multirow{4}{*}{ Source of information* } & Health professional & 61 & $68.5 \%$ \\
\hline & Relatives and friends & 54 & $60.6 \%$ \\
\hline & Mass media & 78 & $87.6 \%$ \\
\hline & Course education & 22 & $24.7 \%$ \\
\hline \multirow{2}{*}{ Benefits of contraception* } & Yes & 89 & $89.0 \%$ \\
\hline & No & 11 & $11.0 \%$ \\
\hline \multirow{5}{*}{ If yes } & Avoid unwanted pregnancy & 84 & $94.3 \%$ \\
\hline & Maintain birth spacing & 71 & $79.7 \%$ \\
\hline & Limit the number of births & 58 & $65.1 \%$ \\
\hline & Decrease economic burden of family & 62 & $69.6 \%$ \\
\hline & Improve health of mother & 37 & $41.5 \%$ \\
\hline
\end{tabular}

\footnotetext{
*Multiple responses.
}

\section{DISCUSSION}

Family planning is defined by WHO as "a way of thinking and living that is adopted voluntarily, upon the basis of knowledge, attitude and responsible decisions by individuals and couples, in order to promote the health and welfare of family groups and thus contribute effectively to the social development of a country." The 
global adoption of family planning in a society is an integral component of social and economic development of a nation.

Table 3: Contraceptive practice among participants $(n=100)$.

\begin{tabular}{|lll|}
\hline Contraceptive method & Number & Percentage \\
\hline Not practising any method & 23 & $23.0 \%$ \\
\hline Condoms & 20 & $20.0 \%$ \\
\hline Oral contraceptive pills & 18 & $18.0 \%$ \\
\hline Injectables & 11 & $11.0 \%$ \\
\hline Copper-T/multiload & 12 & $12.0 \%$ \\
\hline Norplant & 0 & $0.0 \%$ \\
\hline Emergency contraception & 9 & $9.0 \%$ \\
\hline Female sterilization & 5 & $5.0 \%$ \\
\hline Male sterilization & 2 & $2.0 \%$ \\
\hline
\end{tabular}

Table 4: Attitude of non-users towards contraceptive methods $(n=23)$.

\begin{tabular}{|lll|}
\hline Reason of non-usage* & Number & Percentage \\
\hline Unaware & 11 & $47.8 \%$ \\
\hline Fear of side effects & 15 & $65.2 \%$ \\
\hline Want for male child & 6 & $26.0 \%$ \\
\hline Found inconvenient to use & 21 & $91.3 \%$ \\
\hline Found expensive to use & 18 & $78.2 \%$ \\
\hline $\begin{array}{l}\text { Apprehension regarding } \\
\text { effect on future fertility }\end{array}$ & 11 & $47.8 \%$ \\
\hline $\begin{array}{l}\text { Partner objection } \\
\text { (family pressure) }\end{array}$ & 3 & $13.0 \%$ \\
\hline Religious belief & 5 & $21.7 \%$ \\
\hline Think children as god's gift & 2 & $8.6 \%$ \\
\hline $\begin{array}{l}\text { Think MTP as method of } \\
\text { contraception }\end{array}$ & 9 & $39.1 \%$ \\
\hline *Multiple responses. & & \\
\hline
\end{tabular}

Strategies to increase contraceptive use must include improving delivery of correct and adequate information about the availability of contraceptive methods. ${ }^{8}$ Education of women is considered to be a most impartment factor in decision making. ${ }^{9}$ For contraceptive usage, couple's will and motivation is necessary. Awareness and knowledge are the key to choose the right method for contraception.

In this study, result showed that $89 \%$ participants had knowledge about contraception whereas 97.4 and $99 \%$ is seen in other studies conducted at Lahore. ${ }^{10,11}$ Similar result of contraceptive awareness $(87 \%)$ was seen in study conducted by Pegu B et al. ${ }^{12}$ Khan A et al, mentioned that $81 \%$ had awareness regarding any method of contraception. The best-known method of contraception was condoms (88.78) followed by IUCD (77.07\%) and OCP $(72.19 \%){ }^{13}$

In the present study, it was the media (78\%) which had played the most important role in spreading awareness about contraceptive methods among the participants. Tuladhar $\mathrm{H}$ et al, also observed that the most common source of information on contraception was media $(55.5 \%)$, and both printed and electronic. ${ }^{14}$ Similar to this study, Renjhen et al, conducted the study among college students in Sikkim where media had played the most important role in spreading awareness on contraceptive methods. ${ }^{15}$ Another study conducted by Orno-Aghoja et al, from Nigeria in 2009, and Srivastav et al, from India in 2005, social circle was found to be the main source of knowledge followed by health worker. ${ }^{16,17}$

In present study, $23 \%$ of nursing and paramedical staff were not using any method of contraception. Condom was the most common practiced method in this study followed by OCPs. Similar result was shown in other study as well. ${ }^{18-20}$ In contrast, study conducted by Jabeen $M$ et al, commonly used methods were traditional, injectable and female sterilization which is different from the work of Seema et al. ${ }^{21,22}$ The gap between awareness and practices seemed to be prevalent across different reasons. The most common reason for non-practice of contraception was inconvenience to use. Other reasons for non-practice were that participants considered them to be expensive to use, fear of side-effects, apprehension regarding future fertility and religious beliefs. Some participants also thought MTP as a method of contraception. Ghike S, also mentioned various reasons for non-usage of contraceptive methods. ${ }^{23}$

\section{CONCLUSION}

The study concludes that health care providers have heard of family planning through various sources of information. Despite this, some health care providers still do not have adequate knowledge on family planning methods. Knowledge precedes attitude and knowledge and attitude predicts behaviour. Health care providers should be equipped with recent information on all the available family planning methods through intensive inservice trainings, seminars/conferences, etc. This will get them informed and all misconceptions will be erased and in turn each health care provider will be able to make informed choice from the various options of family planning methods and practice the best suitable method.

\section{ACKNOWLEDGMENTS}

Authors would like to thank nursing and para-medical staff who agreed to participate in this study.

\section{Funding: No funding sources}

Conflict of interest: None declared

Ethical approval: The study was approved by the Institutional Ethics Committee

\section{REFERENCES}

1. Survey H. Central Statistical Agency. Ethiopian Demographic and Health Survey 2016 Key 
Indicators Report. Addis Ababa and Maryland, Ethiopia; 2016. Available at: https://dhsprogram.com/pubs/pdf/FR328/FR328.pdf. Accessed 12 $2^{\text {th }}$ March 2020.

2. Park K. Park's Textbook of Preventive and Social Medicine. $17^{\text {th }}$ ed. Jabalpur: Banarasidas Bhanot; 2002:325-358.

3. Renjhen P, Kumar A, Pattanshetty S, Sagir A, Samarasinghe CM. A study on knowledge, attitude and practice of contraception among college students in Sikkim, India. J Turkish Ger Gynecol Assoc. 2010;11:78-81.

4. The Alan Guttmacher Institute. Sharing Responsibility: Women, Society and Abortion Worldwide. Alan Guttmacher Institute; 1999.

5. Stillman M, Frost JJ, Singh S, Moore AM, Kalyanwala S. Abortion in India: A literature review, New York, Guttmacher Institute; 2014:12-4.

6. Weldegerima B, Denekew A. Women's knowledge, preferences, and practices of modern contraceptive methods in Woreta, Ethiopia. Res Social Adm Pharm. 2008;4:302-7.

7. Jahan U, Verma K, Gupta S, Gupta R, Mahour S, Kirti N, et al. Awareness, attitude and practice of family planning methods in a tertiary care hospital, Uttar Pradesh, India. Int J Reprod Contracept Obstet Gynecol. 2017;6:500-6.

8. Kaushal SK, Saxena SC, Srivastava VK, Gupta SC, Nigam S. KAP study on contraceptive methods in Kanpur district of UP. Indian J Commun Health. 2009-2010;21(2):33-8.

9. Cindoglu D, Sirkeci I, Sirkeci RF. Determinants of choosing withdrawal over modern contraceptive methods in Turkey. Eur J Contracept Reprod Health Care. 2008;13:412-21.

10. Hakim A, Sultan M, Ahmed F. Pakistan reproductive health and family planning survey 2001. In: Hakim A, Sultan M, Ahmed F, eds. The Institute. Islamabad: The Institute; 2001:60-62.

11. Humayun S. Knowledge and practices of family planning in grand multiparas. J Coll Physicians Surg Pak. 2002;12:522-5.

12. Pegu B, Gaur BPS, Sharma N, Singh AS. Knowledge, attitude and practices of contraception among married women. Int $\mathbf{J}$ Reprod Contracept Obstet Gynaecol. 2014;3:385-8.

13. Khan A, Hashmi HA, Naqvi Z. Awareness and practice of contraception among Child Bearing Age Women. J Surg Pak. 2011;16(4):179-82.
14. Tuladhar H, Marahatta R. Awareness and contraception practices among women attending gyne OPD at Nepal medical college teaching hospital. Nepal Med Coll J. 2008;10(3):184-91.

15. Renjhen P, Kumar A, Pattanshetty S, Sagir A, Samarasinghe CM. A study on knowledge, attitude and practice of contraception among college students in Sikkim, India. J Turkish-German Gynecol Assoc. 2010;11:78-81.

16. Chigbu B, Onwere S, Aluka C, Kamanu C, Okoro O, Feyl-Waboso P. Contraceptive choices of women in rural Southern Nigeria. Niger J Clin Pract. 2010;13:195-9.

17. Srivastava R, Srivastava DK, Jina R, Srivastava K, Sharma N, Sana S. Contraceptive knowledge, attitude and practice (KAP Survey). J Obstet Gynaecol India. 2005;55:546-50.

18. Khawaja NP, Tayyab R, Malik N. Awareness and practices of contraception among Pakistani women attending a tertiary care hospital. J Obstet Gynaecol. 2004;24:564-7.

19. Oyedeji OA, Cassimjee R. A gendered study of young adult contraceptive use at one university in Kwa Zulu-Natal. Curationis. 2006;29(3):7-14.

20. Brahmbhatt MM, Sheth JK, Balaramanamma DV. A study of knowledge, attitude and practice towards contraception among married women of reproductive age group having $\leq 2$ children residing in Vasna ward, Ahmedabad, Gujarat, India. Healthline. 2013;4(2):8-12.

21. Bibi S, Memon A, Memon Z. Contraceptive knowledge and practices in two districts of Sindh Pakistan-A hospital-based survey. JPMA. 2008;58:254-7.

22. Jabeen M, Fouzia G, Farmanullah W, Nargis J. Knowledge, attitude and practices of Contraception in women of reproductive age. Gomal J Med Sci. 2011;9(2):223-9.

23. Ghike S, Joshi S, Bhalerao A, Kawthalkar A. Awareness and contraception practices among women an Indian Rural experience. J South Asian Federation Obstet Gynaecol. 2010;2(1):19-21.

Cite this article as: Garg P. Knowledge, attitude and practice of contraception among nursing and paramedical staff in a tertiary care hospital of Mathura, Uttar Pradesh, India. Int J Reprod Contracept Obstet Gynecol 2020;9:2234-8. 